\title{
Genetic parameters for egg production in meat quails through partial periods
}

\author{
Jeferson Corrêa Ribeiro ${ }^{1^{*}}$ Luciano Pinheiro da Silva $^{2}$ Aline Camporez Crispim Soares ${ }^{3}$ \\ Giovani da Costa Caetano ${ }^{3}$ Carla Daniela Suguimoto Leite $^{3}$ Cristina Moreira Bonafé $^{4}$ \\ Mariele Freitas Sousa ${ }^{3}$ Robledo de Almeida Torres ${ }^{3}$
}

\author{
${ }^{1}$ Departamento de Zootecnia, Instituto Federal Goiano, CP 92, 75650-000, Campus Morrinhos, Morrinhos, GO, Brasil. E-mail \\ jeferson.ribeiro@ifgoiano.edu.br. "Corresponding author. \\ ${ }^{2}$ Departamento de Zootecnia, Universidade Federal do Ceará (UFC), Fortaleza, CE, Brasil. \\ ${ }^{3}$ Departamento de Zootecnia, Universidade Federal de Viçosa (UFV), Viçosa, MG, Brasil. \\ ${ }^{4}$ Departamento de Zootecnia, Universidade Federal dos Vales do Jequitinhonha e Mucuri (UFVJM), Diamantina, MG, Brasil.
}

\begin{abstract}
We estimated genetic and phenotypic parameters for egg production in meat-type quails aiming to propose an optimal age for selection through partial record egg production. Data of 3,503 female quails from two strains (namely, UFV1, with 1,811 and UFV2 with 1,692 females) were used. Egg production was assessed by the number of eggs recorded after 42 days of age and each partial period consisted on 35 days of egg production forward. Covariance components were estimated by using single and bivariate animal model, comprising each partial period of egg production and full egg production period (one year of egg laying). Regarding strain UFV1, heritability estimates ranges from 0.03 to 0.16 , and for strain UFV2 0.20 to 0.25. The highest genetic correlation with full egg production was with second period (0.64) for strain UFV1 and with third period (0.47) for UFV2. Therefore, animal selection based on egg production until 112 days for the strain UFV1 and 147 days for the strain UFV2 provided increased genetic gain by reducing generation interval.
\end{abstract}

Key words: Coturnix coturnix, genetic correlation, genetic evaluation, heritability, variance components.

Estimação de parâmetros genéticos para produção de ovos em codornas de corte através de períodos parciais

RESUMO: Este estudo teve como objetivo estimar os parâmetros genéticos e fenotípicos para a produção de ovos de codornas de corte e propor uma idade ideal para a seleção através da característica de produção de ovos. Os dados utilizados neste estudo vieram de 3.503 codornas de duas linhagens (1.811 fêmeas UFV1 e 1.692 fêmeas UFV2). A produção de ovos foi avaliada pelo número de ovos coletados a partir do 42 dia de vida em diante, usando modelo animal uni ou bicaracterístico, em periodos parciais de 35 dias cada e periodo total (um ano de postura). Para a linhagem UFV1, as estimativas de herdabilidade variaram de 0,03 a 0,16, e para a linhagem UFV2, de 0,20-0,25. A correlação genética maior foi entre o segundo periodo e total $(0,64)$ para a linhagem UFV1 e 0,47 (terceiro período e total) para UFV2. Portanto, recomenda-se usar o período de produção de ovos até 112 dias para a linhagem UFV1 e o período de produção de ovos até 147 dias para a linhagem UFV2, permitindo, assim, uma redução no intervalo de geração.

Palavras-chave: avaliação genética, componentes de variância, correlação genética, Coturnix coturnix, herdabilidade.

\section{INTRODUCTION}

Egg production in poultry depends on age when first egg is laid, egg-laying rate and laying persistence, being these the main factors for selection in laying birds (BOUKILA et al., 1987). In Brazil, laying quail peak of egg production ranges between 93 to $95 \%$, whereas meat quail reaches 80 to $85 \%$. Full egg production period in quail is about 9 to 12 months and selection on full egg production can result in greater genetic gain for this trait. However, using these records increases generation interval, since it is only recorded at the end of the laying cycle. Animals selected at 12 months age present either low laying and fertility rates, which may endanger these breeding populations. Since full period egg production and egg production on a partial record period are supposed to be correlated, animals can be selected earlier with gains by indirect selection, which means that 
cumulative egg production during an early phase of production is a potential selection criterion. Thus, the choice of the partial record egg production with highest correlation with the whole egg production period could reduce generation interval, possibly increasing selection intensity and reducing costs.

The use of partial periods as selection criteria on laying hens is well known (DEMPSTER \& LERNER, 1947; LERNER \& CRUDEN, 1948; BOHREN et al., 1970) and these authors concluded that using records of partial periods to select animals is about $50 \%$ more effective than selection based on a year laying. However, no such studies were conducted in meat quail.

The aim of this study was to estimate genetic and phenotypic parameters for egg production in meat quails; to study genetic associations between egg production considering partial periods and full period; and to propose an optimal age to select the animals for increased egg production.

\section{MATERIALS AND METHODS}

Data from two strains of meat quail (Coturnix coturnix) from Poultry Breeding Program at Department of Animal Sciences of the Universidade Federal de Viçosa, Brazil were used in this study. Animals were originally acquired from two different farms and named strains UFV1 and UFV2. Founder population consisted on 232 animals (149 females and 83 males) for strain UFV1 and 185 animals (119 females and 66 males) for UFV2. First generation was originated from founders, and offsprings were reproduced through 10 generations. The relationship matrix contained information from 13,648 animals for strain UFV1 and 14,196 animals for UFV2. We used records from all 10 generations of females, totalizing 1,811 records for UFV1 and 1,692 for UFV2.

Birds from both strains were housed in concrete floor lined with bedding shavings, enclosure by a steel protection circle and heated through heat brooders during the first phase of rearing. Up to the 42 nd day of age, diet were composed by $26 \%$ of crude protein and $2,950 \mathrm{Kcal}$ of metabolizable energy per $\mathrm{kg}$. Water and feed were provided ad libitum.

Lighting programs of 24 hours were utilized from birth until 21 st days of age. From the 21 st to the 28th days of age animals were submitted to natural lighting. Animal selection based on body weight was performed at the 28th day of age, when 204 females and 102 with higher body weight within each strain were selected, at every generation, corresponding to about $20 \%$ of selected animals. The choice for these numbers of selected animals was due to the number of breeding cages. The same effective size, mating type and selection were used for both strains. After selection, animals were transferred to individual galvanized cages and randomly mated on a ratio of two females per male. Lighting program of 16 hours was adopted. These procedures were repeated in every generation.

Egg production was defined by the number of eggs from the 42 nd to 407 days of age, totalizing one year of egg laying. We analyzed four periods of partial egg production comprising 35 days each: partial production of eggs from 42 to 77 days (N77), from 77 to 112 days (N112), from 112 to 147 days (N147), from 147 to 182 days (N182) and the whole production period, from 42 to 407 days (N407). Choice of period time was based on age at first egg (N77), and periods before, during and after laying peak (N112, N147 and N182). Average age of first egg was $53.27( \pm 9.56)$ days for strain UFV1 and $52.93( \pm 9.23)$ days for UFV2. Females who did not start laying at first period or with less than one standard deviation of overall laying (N407) were removed from the analysis. Consistence and structure analysis of data were performed using the SAS software, version 9.3 (Statistical Analysis System Institute, Cary, NC, USA).

Covariance components and genetic parameters were estimated by Restricted Maximum Likelihood Method using animal model univariate analysis. Bivariate analysis were performed to estimate genetic correlation among partial and whole periods and high dimensional multivariate analysis were avoided as well to prevent severe multicolinearity among variables. Generation/ hatch was considered as fixed effect and all analysis were performed using REMLF90 software (MISZTAL, 2002). The following animal model was considered:

$\mathbf{y}=\mathbf{X} \boldsymbol{\beta}+\mathbf{Z} \boldsymbol{\alpha}+\mathbf{\varepsilon}$

Where $\mathbf{y}$ is the vector of records; $\mathbf{X}$ is the incidence matrix for fixed effects; $\beta$ is the vector of fixed effects; $\mathbf{Z}$ is the incidence matrix for the random effects; $\alpha$ is the vector of random effects and $\varepsilon$ is the vector of residuals.

Relative efficiency (RE) of selection based on partial period compared to whole period was calculated according to the formula described by FALCONER (1996):

$R E=\frac{h_{p p} \cdot r_{g}}{h_{w p}}$ 
where $h_{p p}$ is the square root of heritability at partial period; $h_{w p}^{p p}$ is the square root of heritability at whole period and $r_{g}$ is the genetic correlation between partial and whole periods.

If the ratio of relative efficiency is higher than one, indirect selection is favorable and genetic gain will be greater than direct selection.

Evaluation of expected correlated response using partial records compared to whole period was performed using the following equations LOPES et al. (2005):

$$
\begin{aligned}
& \Delta G_{p}=i\left(h_{p p}^{2} \cdot \sigma_{p p}+r_{g} \cdot h_{p p} \cdot h_{w p} \cdot \sigma_{w p}\right) \\
& \Delta G_{p}=i \cdot \sigma_{w p} \cdot h_{w p}^{2}
\end{aligned}
$$

where $\Delta G_{p}$ is the genetic gain on whole period, by selection on partial record; $\Delta G_{\mathrm{a}}$ is the genetic gain based on direct selection; $i$ is the selection intensity; $h_{p p}^{2}$ is the heritability of partial period of laying; $h_{w p}^{2}$ is the heritability of whole period of laying; $\sigma_{p p}$ is the standard deviation of partial period of laying; $\sigma_{w p}$ is the standard deviation of whole period of laying and $r_{g}$ is the genetic correlation between periods.

\section{RESULTS AND DISCUSSION}

Descriptive statistics of egg production, such as mean with standard deviation, coefficient of variation and standard error of the mean, for strain UFV1 and UFV2 were on table 1. Results presented for both strains agreed with those reported by TEIXEIRA et al. (2012) and DIONELLO et al. (2011) with meat-type quails. However, GEORG et al. (2009) reported higher values of mean egg production when evaluated laying quails.

Comparisons between two populations evaluated were not considered because they originated from different farms. There are no knowledge about the previous mating system, selection history, and the number of traits used for selection these populations have been submitted before establishment of the present breeding program. All variables mentioned before were controlled and animals were kept to the same environmental conditions for both populations through the generations. However, it was possible to note that these populations had different allelic fixation along the selection process, which could resulted on divergent heritability and genetic correlations estimates. Although the environment was the same for both populations, differences on genetic parameters estimate might be due to divergent environmental adaptation or level of fixation of alleles.

The difference on performance between meat and laying quails is due to selection over years leading to line specialization. Selection to increase body weight often implies on decrease on egg production. Antagonism between these traits where also observed by VAYEGO et al. (2008); SZINVELSKI, et al. (2011) and CRUZ et al. (2013).

The period with highest coefficient of variation was N77 (48.90\% and $47.26 \%$ for UFV1 and

Table 1 - Egg production means and respective standard deviation (SD), coefficient of variation (CV) and standard error of the mean (SEM)

\begin{tabular}{|c|c|c|c|c|}
\hline Partial Periods & Means (eggs producedhen ${ }^{-1}$ ) & SD & $\mathrm{CV}(\%)$ & SEM \\
\hline N77 & 18.68 & 9.13 & 48.90 & 0.23 \\
\hline $\mathrm{N} 112$ & 47.59 & 14.30 & 30.04 & 0.36 \\
\hline N147 & 76.46 & 20.96 & 27.41 & 0.53 \\
\hline N182 & 104.79 & 28.41 & 27.12 & 0.72 \\
\hline N407 & 281.95 & 46.64 & 16.54 & 2.05 \\
\hline \multicolumn{5}{|c|}{ } \\
\hline N77 & 19.22 & 9.08 & 47.26 & 0.23 \\
\hline $\mathrm{N} 112$ & 46.72 & 14.67 & 31.40 & 0.36 \\
\hline N147 & 65.06 & 25.49 & 39.17 & 0.62 \\
\hline N182 & 125.49 & 50.97 & 39.17 & 1.24 \\
\hline N407 & 279.56 & 47.76 & 17.08 & 2.37 \\
\hline
\end{tabular}
for strains UFV1 and UFV2.

N77 - egg production in the partial periods from 42 to 77 days; N112 - from 77 to 112 days; N147 - from 112 to 147 days; N182 - from 147 to 182 days and $\mathrm{N} 407$ - full period (from 42 to 407 days). 
UFV2, respectively). Higher coefficient of variation at this period was expected because egg production is erratic at the beginning. Similar results were also reported by VENTURINI et al. (2012) on laying hens.

Heritability values were different for strains UFV1 and UFV2 and were presented on table 2. Regarding to UFV1, egg production heritability ranged from 0.03 to 0.16 . Similar values were reported by DIONELLO et al. (2011), TEIXEIRA et al. (2012), TEIXEIRA et al. (2013a) and TEIXEIRA et al. (2013b) on studies with meat quails. Regarding to UFV2, estimate of heritability from 0.20 to 0.25 were observed. Similar results were reported by MIELENZ et al. (2006), which pointed moderate heritability $(0.35$ and 0.21$)$ for two meat quail strains considering egg production until 200 days.

Reproductive traits usually have low values of heritability due to a great influence of environmental effects on trait variation. Even on populations kept under same environmental conditions, low heritability could be observed due to homozygosity for specific trait, leading to smaller genetic variance and, in consequence, lower heritability estimate compared to population with higher heterozygosity (PEREIRA, 2004).

Divergent values of heritability can be easily reported on literature for quails and also laying hens. SAVEGNAGO et al. (2011) and VENTURINI et al. (2012) pointed low heritability estimate while
BESBES et al. (1992) and ONI et al. (2007) observed moderate heritability for egg production traits. Thus, heritability variations observed between strains UFV1 and UFV2 could be also acceptable for meat quail.

Genetic, environmental and phenotypic correlations were estimated for all partial periods and the whole laying period and were presented in table 3 . The highest genetic correlation estimate was between N112 and N407 (0.64) for the strain UFV1. Genetic correlation between whole period and other partial periods (N77xN407, N147xN407 and $\mathrm{N} 182 \times \mathrm{N} 407$ ) ranged from 0.34 to 0.49 for UFV1 and 0.44 to 0.47 for UFV2.

Genetic correlations were lower than those reported by VIETA et al. (1980), which obtained correlation between partial and full egg production periods ranging from 0.49-0.99 and 0.71-0.99 for Japanese quail, respectively; ONI et al. (2007) and SAVEGNAGO et al. (2011) observed genetic correlation between partial and full for the same trait ranging from 0.83 to 0.96 and 0.67 to 0.94 for laying hens, respectively. Moreover, number of partial periods evaluated and number of days on each period must be considered when comparing genetic correlations.

Higher correlations among adjacent records are expected probably due to similar gene action over time. Earlier laying periods have more influence of genes related to age at sexual maturity as for late periods genes related to persistence are more influents (WOLC \& SZWACZKOWSKI, 2009).

Table 2 - Estimates of heritability $\left(h^{2}\right)$, additive genetic variances $\left({ }^{\sigma_{a}^{2}}\right)$, environmental variances $\left({ }^{\sigma_{e}^{2}}\right)$ and phenotypic variances $\left({ }^{\sigma_{p}}\right)$ of egg production for strains UFV1 and UFV2.

\begin{tabular}{|c|c|c|c|c|}
\hline Partial Periods & $h^{2}$ & $\sigma_{a}^{2}$ & $\sigma_{e}^{2}$ & $\sigma_{p}^{2}$ \\
\hline \multicolumn{5}{|c|}{ 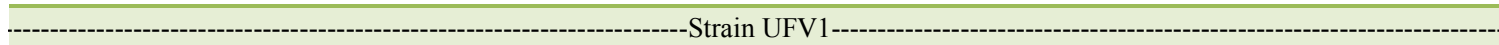 } \\
\hline N77 & 0.03 & 1.86 & 53.95 & 55.81 \\
\hline N112 & 0.06 & 11.76 & 174.00 & 185.76 \\
\hline N147 & 0.07 & 29.06 & 380.80 & 409.86 \\
\hline $\mathrm{N} 182$ & 0.08 & 60.16 & 715.60 & 775.76 \\
\hline N407 & 0.16 & 337.30 & $1,790.00$ & $2,127.30$ \\
\hline \multicolumn{5}{|c|}{ 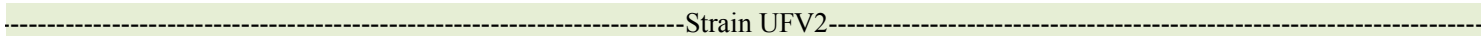 } \\
\hline N77 & 0.20 & 7,97 & 32.20 & 40.17 \\
\hline N112 & 0.23 & 26.63 & 89.05 & 115.68 \\
\hline N147 & 0.25 & 62.23 & 185.26 & 247.49 \\
\hline N182 & 0.25 & 248.90 & 741.06 & 989.96 \\
\hline N407 & 0.22 & 426.51 & $1,518.50$ & $1,945.00$ \\
\hline
\end{tabular}

N77 - egg production in the partial periods from 42 to 77 days; N112 - from 77 to 112 days; N147 - from 112 to 147 days; N182 - from 147 to 182 days and N407 - full period (from 42 to 407 days). 
Table 3 - Estimate genetic $\left(r_{g}\right)$, environmental $\left(r_{e}\right)$ and phenotypic $\left(r_{p}\right)$ correlations between each partial period (N77, N112, N147 and N182) and full period (N407); and relative efficiency for strains UFV1 and UFV2.

\begin{tabular}{|c|c|c|c|c|}
\hline Partial Periods & $\mathrm{r}_{\mathrm{g}}$ & $\mathrm{r}_{\mathrm{e}}$ & $\mathrm{r}_{\mathrm{p}}$ & Relative Efficiency \\
\hline \multicolumn{5}{|c|}{$\begin{array}{l}- \\
-\end{array}$} \\
\hline N77 & 0.36 & 0.24 & 0.22 & 0.16 \\
\hline N112 & 0.64 & 0.26 & 0.27 & 0.40 \\
\hline N147 & 0.49 & 0.32 & 0.32 & 0.32 \\
\hline N182 & 0.34 & 0.34 & 0.30 & 0.24 \\
\hline \multicolumn{5}{|c|}{ 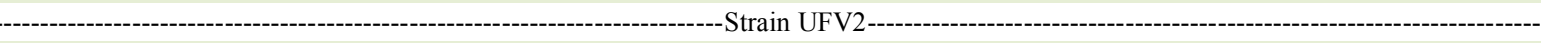 } \\
\hline N77 & 0.47 & 0.12 & 0.20 & 0.45 \\
\hline N112 & 0.44 & 0.13 & 0.20 & 0.45 \\
\hline N147 & 0.46 & 0.14 & 0.22 & 0.49 \\
\hline N182 & 0.46 & 0.14 & 0.22 & 0.49 \\
\hline
\end{tabular}

N77 - egg production in the partial periods from 42 to 77 days; N112 -from 77 to 112 days; N147 -from 112 to 147 days; N182 -from 147 to 182 days and N407 - full period (from 42 to 407 days).

Relative efficiency values were low to moderate (0.16-0.40 for UFV1 and $0.45-0.49$, for UFV2) and were presented on table 3 . These results, associated with low to moderate correlation estimates indicates that selection using partial record egg production may result in few gains compared with selection using full production information.

Direct response on whole egg production yields greater results when compared to correlated responses. The cases which direct selection would not yield to better result in comparison with indirect selection are: environmental factors in different periods are very dissimilar; low genetic correlation; and high differences in heritability (SILVA et al., 2001).

The use of full egg production could result on shorter generation intervals. Thus, partial period approach considering correlation and relative efficiency could provide genetic gains though indirect response and also reduce generation interval. Results for strain UFV1 indicated that partial period N112 presented highest genetic correlation with full production N407 and could be used as criterion to select quails for egg production. For strain UFV2, period N147 presented highest heritability and relative efficiency among other periods and moderate genetic correlation with N407.

Heritability and phenotypic standard deviations among complementary period and N112 (0.13 and 130.5) to strain UFV1 and N147 (0.66 and $46.30)$ to strain UFV2 were calculated in order to evaluate genetic gain (LOPES et al., 2005). In terms of selection response, selecting animals based on partial egg production lead to an increase of 10.56 eggs per year on strain UFV1, while the same method results on increase of 10.45 eggs per year.

The same pattern where observed on strain UFV2, which had a genetic improvement of 30.51 through selection based on partial period N147 while selection based on whole period of egg production provided a genetic improvement of 14.71 . Selection based on information of partial period lead to lower genetic improvement if just one generation is considered. However, it is reasonable to compare genetic improvement on the same time interval on breeding programs (LOPES et al., 2005). In this way, selection by partial period production can allow performing more generations per year, reducing the generation interval and increasing the selection intensity, overcoming genetic improvement through selection considering whole egg production period.

\section{CONCLUSION}

Regarding the strain UFV1, heritability estimates for partial and full egg production were low. Low to moderate genetic correlation between partial and full egg production indicate that selection based on partial periods might not result in satisfactory genetic gains. However, selection of meat quails considering the egg production until 112 days of age can be considered viable because it enabled to reduce the generation interval and perform up to three generations per year. Regarding the strain UFV2, moderate heritability and genetic correlation between partial and full period of egg production, combined with low relative efficiency also indicated that selection for egg production through partial periods would also not provide satisfactory 
genetic gains when compared with full production. However, animal selection based on egg production until 147 days of age would reduce the generation interval and allow performing up to two generations per year, indicating that selection using information of partial periods could provide greater genetic improvement per year in comparison with selection based on full period.

\section{BIOETHICS AND BIOSSECURITY COMMITTEE APPROVAL}

The protocol of experiments using animals is in accordance with Conselho Nacional de Controle de Experimentação Animal (CONCEA) and was approved by ethical committee from the Universidade Federal de Viçosa (UFV), protocol number 73/2014.

\section{ACKNOWLEDGEMENTS}

We thank the Conselho Nacional de Desenvolvimento Científico e Tecnológico (CNPq), process 142696/2010-2, Coordenação de Aperfeiçoamento de Pessoal de Nível Superior (CAPES) and Fundação de Amparo à Pesquisa do estado de Minas Gerais (FAPEMIG) for financial support.

\section{REFERENCES}

BOHREN, B.B. Genetic gains in annual egg production from selection on part-record percent production in the fowl. Genetics, v.65, p.655-667, 1970. Available from: <http://www.genetics.org/ content/genetics/65/4/655.full.pdf>. Accessed: Apr. 10, 2016.

BOUKILA, B. et al. Selection for increased egg production based on annual record in three strains of white Leghorns. Comparison of different partial records to improve annual egg production. Poultry Science, v.66, p.1077-1084, 1987. Available from: <http:// ps.oxfordjournals.org/content/66/7/1077.abstract>. Accessed: Apr. 10, 2016. doi: 10.3382/ps.0661077.

CRUZ, V.A.R. et al. Evaluation of posture rating curves of a female line of broilers. Ciência Rural, v.43, n.3, p.520-523, 2013. Available from: $\quad<$ http://www.scielo.br/scielo.php?script=sci arttext\&pid=S0103-84782013000300024\&lng $=\mathrm{e} \quad \mathrm{n} \& \mathrm{nrm}=\mathrm{iso}>$. Accessed: Aug. 01, 2016.

DEMPSTER, E.R.; LERNER, I.M. The optimum structure of breeding flock. Rate of genetic improvement under different breeding plans. Genetics, v.32, p.555-566, 1947. Available from: <http://www.genetics.org/content/32/6/555>. Accessed: Apr. 03, 2013.

DIONELLO, N.J.L. et al. Produção em número, peso e massa de ovos em codornas de corte até 406 dias de idade. PUBVET, v.5, n.27, p.1171-1177, 2011. Available from: <http://www.pubvet. com.br/uploads/14e198411014dc228e0628e3f777c44f.pdf $>$. Accessed: Aug. 01, 2016.

FALCONER, D.S. Introduction to quantitative genetics. 4.ed. Harlow: Longman, 1996. 480p.

GEORG, P.C. et al. Genotype-environment interaction in laying quail fed diet with two levels of metabolizable energy. Brazilian Journal of Animal Science, v.38, p.1706-1711, 2009. Available from: <http://www.scielo.br/pdf/rbz/v38n9/09.pdf $>$. Accessed: Aug. 01, 2016.

LERNER, I.M.; CRUDEN, D.M. The heritability of accumulative monthly and of annual egg production. Poultry Science, v.27, p.57-78, 1948. Available from: <http://ps.oxfordjournals. org/content/27/1/67.abstract $>$. Accessed: Dec. 14, 2012. doi: $10.3382 /$ ps.0270067.

LOPES, P.S. et al. Teoria do melhoramento animal. Belo Horizonte: FEPMV, 2005. 118p.

MIELENZ, N. Estimation of additive and non-additive genetic variances of body weight, egg weight and egg production for quails (Coturnix coturnix japonica) with an animal model analysis. Archives Animal Breeding, v.49, n.3, p.300-307, 2006. Available from: <http://arch-anim-breed.fbn-dummerstorf.de/ pdf/2006/at06p300.pdf $>$. Accessed: Aug. 02, 2016.

MISZTAL, I. REMLF90 manual. 2002. Available from: <http:// nce.ads.uga.edu/ ignacy/Numpub/blupf90/docs/remlf90.pdf $>$. Accessed: Jun. 26, 2010.

ONI et al. Genetic and phenotypic relationships between mcnally model parameters and egg production traits. International Journal of Poultry Science, v.6, n.1, p.8-12, 2007. Available from: <http://docsdrive.com/pdfs/ansinet/ijps/2007/8-12.pdf>. Accessed: Apr. 10, 2016.

PEREIRA, J.C.C. Melhoramento genético aplicado à produção animal. 4.ed. Belo Horizonte: FEPMVZ, 2004. 609p.

SAVEGNAGO, R.P. et al. Estimates of genetic parameters, and cluster and principal components analysis of breeding values related to egg production traits in a White Leghorn population. Poultry Science, v.90, p.2174-2188, 2011. Available from: $<$ http://ps.oxfordjournals.org/content/90/10/2174.full.pdf + html $>$. Accessed: Apr. 11, 2016. doi: 10.3382/ps.2011-01474.

SILVA, M.V.G.B. et al. Correlated responses in the reproductive traits in the breeding program of mantiqueira cattle for milk production. Brazilian Journal of Animal Science, v.30, n.4, p.1228-1235, 2001. Available from: < http://www.scielo.br/pdf/rbz/ v30n4/6030.pdf>. Accessed: Aug. 01, 2016.

SZINVELSKI, R.G. et al. Genetic parameters for production characteristics in male lineage of arrays of broilers: heritabilities and correlations. PUBVET, v.5, n.35, p.12241230, 2011. Available from: <http://www.pubvet.com.br/ uploads/e8cf319fa84aab6605668ec7bc32c725.pdf>. Accessed: Aug. 01, 2016.

TEIXEIRA, B.B. et al. Estimative of the variances components for eggs production and quality characteristics in meat-type quail. Ciência Rural, v.42, p.713-717, 2012. Available from: <http:// dx.doi.org/10.1590/S0103-84782012000400023>. Accessed: Apr. 11, 2016.

TEIXEIRA, B.B. et al. Random regression models in the selection of meattype quails for egg production. Pesquisa Agropecuária Brasileira, v.48, n.7, p.791-796, 2013a. Available from: <http:// dx.doi.org/10.1590/S0100-204X2013000700012>. Accessed: Aug. 01, 2016.

TEIXEIRA, B.B. et al. Heritability of production and laying traits in meat-type quails. Ciência Rural, v.43, n.2, p.361-365, 2013b. 
Available from: < http://www.scielo.br/pdf/cr/v43n2/a3513cr5038. pdf>. Accessed: Aug. 01, 2016.

VALI, N. The Japanese quail: a review. International Journal of Poultry Science, v.7, n.9, p.925-931, 2008. Available from: $<$ http://www.pjbs.org/ijps/fin1218.pdf $>$. Accessed: Aug. 02, 2016.

VAYEGO, S.A. et al. Estimates of genetic parameters and trends for performance traits in paternal broiler lineages under selection. Brazilian Journal of Animal Science, v.37, n.7 p.1230-1235, 2008. Available from: <http://dx.doi.org/10.1590/S151635982008000700013>. Accessed: Aug. 01, 2016.

VENTURINI, G.C. et al. Estimation of genetic parameters for partial egg production periods by means of random regression models. Genetics Molecular Research, v.11, p.1819-1829, 2012. Available from: <http://dx.doi.org/10.4238/2012.July.10.18>. Accessed: Apr. 11, 2016.

VIETA, F. et al. Correlaciones entre postura parcial, total y residual em dos subpoblaciones de Codorniz Japonesa (Coturnix coturnix japonica). Revista Cubana de Ciencia Avícola, v.7, p.71-78, 1980. Available from: <http://www.iia.cu/art12.php >. Accessed: May 03, 2013.

WOLC, A.; SZWACZKOWSKI, T. Estimation of genetic parameters for monthly egg production in laying hens based on random regression models. Journal of Applied Genetics, v.50, p.41-46, 2009. Available from <http://www.livestockscience.com/ article/S1871-1413(13)00070-X/pdf>. Accessed: Sept. 23, 2016. 